\title{
Analysis of Marketing Efficiency of Wheat in Different Grade Regulated Markets in Madhya Pradesh
}

\author{
Ravi Singh Chouhan ${ }^{1}$, H.K. Niranjan ${ }^{1}$, Hari Om Sharma ${ }^{2}$ and R.S. Raghuwanshi ${ }^{2}$ \\ ${ }^{1}$ Research Scholar, Mahatma Gandhi Chitrakoot Gramoday Vishwavidyalaya, Chitrakoot, Satna, Madhya Pradesh, India \\ ${ }^{2}$ Professors \& Associate Professors, Jawaharlal Nehru Krishi Vishwa Vidyalaya, Adhartal, Jabalpur, India \\ ${ }^{1}$ Corresponding author: rsc.aerc@gmail.com
}

\begin{abstract}
Marketers need to design creative solutions like e- marketing to overcome challenges typical of the rural environment such as physical distribution, channel management promotion and communication. The study has been undertaken to examine the facilities and services available and to analyse the marketing efficiency of wheat in different grade regulated markets of Madhya Pradesh. The present investigation is restricted to Sehore (A), MHOW (B), Kalapipal (C) and Katangi (D) grade regulated markets in Madhya Pradesh. The study reveals that A grade (Sehore) regulated market was found to facilitate more as compared to the other market but this particular market was found less price efficient than the other market. All the markets has poor market facilities with regards to post office, restaurant, fire extinguishers, bank, grading and analysing laboratory, extension unit, public address system, rest house for farmers, audio visual aid and garbage disposal system. Hence suggested that these facilities should be provided in each regulated markets with National e-agriculture market (e-markets) and bringing them all to one platform so that registered farmers will be able to sell their produce online in any of the markets where they can get the best price. The e-market also ensured that intermediaries (and money lenders) do not compel farmers to sell their produce at throw away prices and their produce should first be bought at the regulated market to be put for auction to sell, which will get them all a fair price, reduce the chances of middlemen by adding any extra cost or seeking double commission. This will also brought transparency in the system.
\end{abstract}

Keywords: Marketing efficiency, regulated markets, Madhya Pradesh

India is second largest producer of Wheat in the world after China with about $13.1 \%$ share in total world Wheat production (DGFT, 2015). Now, India is surplus and in a position to export Wheat in the International Market and can earn foreign exchange. Madhya Pradesh has emerged as one of the leading wheat production states in the country in the last five years (M. Krishnamurthy, 2012) and won Krishi Karman Award continuously in fifth year (2016-17). The State has also improved its position as the third largest wheat producing state in the country after UP and Punjab with a record-break production of 13.13 million tonnes of wheat in the fiscal year 201213 and 13.93 million tonnes in 2013-14 (Anonymous, 2013). Madhya Pradesh contributes $18.57 \%$ of the total wheat production in the country. Sharbati and
Durum Wheat have given an international identity to Madhya Pradesh (Anonymous, 2015).

The agricultural marketing plays an important role not only in stimulating production and consumption, but also in accelerating the pace of economic development. It is dynamic function but of primary importance in promoting economic development. It has been described as the most important multiplier of agricultural development for this reason. India's age-old farming practices have taken a turn in recent years. There has been a technological breakthrough because of the evolution of high yielding variety seeds, increasing consumption of fertilizer, insecticides, pesticides, the installation of pump sets, and tractorization in crop 
husbandry. This technological breakthrough has led to a substantial increase in production on the farms as well as to the larger marketable and marketed surplus of crop. To maintain this tempo and pace of increased production through technological development, an assurance of remunerative prices to the farmers are a prerequisite and this assurance can give to the farmer by developing an efficient marketing system. The efficient marketing system is of vital importance to an area under all condition and each stage in its development. In areas of dense population living at subsistence level, the seasonal failure of a basic food crop can bring about wide spread famine and suffering, meanwhile other parts of the same country may be holding supplies more than adequate for their needs. Such disaster are lessened by transportation and readily available buffer stock facilities, availabilities of communication between one part to another, availabilities of information on current stocks and future requirement, and the reliability of the existing trade organization in recognizing and responding to needs of the community. All these conditions reflect the role of marketing in the overall set up of the area.

The efficient functioning of markets provides remunerative prices to the producers and fair prices to the consumers. Market integration and price transmission, in the case of a large producing and consuming country like India; depend on the geographical dispersion or concentration of production (Acharya et al. 2012). The price variations are common in agricultural commodity mainly because of seasonality in production and inter market arrivals and forced to sale cause decline in price and the intermediate functionaries reap the benefit of such large income (Asmatoddin et al. 2009).

Madhya Pradesh State Agricultural Marketing Board i.e. MPSAMB (also known as Mandi Board) has come into existence w.e.f 1973 under the provisions of M.P. Krishi Upaj Mandi Adhiniyam 1972. Presently in Madhya Pradesh there are a total of 538 regulated markets of which 258 are main wholesale markets having elaborate infrastructure also known as Krishi Upaj Mandi and the balance 280 having lower level of infrastructure known as Sub Mandi. In addition to these there are haat bazars in the rural areas where farmers and other people come together from time to time to sell their farm marketable surpluses and buy their essential requirements.

In Madhya Pradesh, 258 main wholesale markets were categorized into A (51), B (40), C (58) and D (109) grade on the basis of annual revenue collected through the payment of mandi tax by buyers (Table 1 ). The A grade mandies are largest with a gross annual income of over ₹ 40 Lakh, B grade mandies have a gross annual income between ₹ 20 to 40 Lakh, $\mathrm{C}$ grade mandies annual revenue between $₹ 6$ to 20 Lakh and D grade have a gross annual income lower than ₹ 6 Lakh (Anonymous, 2015). Keeping these reviews in mind the present study has been undertaken with following specific objectives:

1. To examine the facilities \& services available and profile of different grade regulated markets of wheat in Madhya Pradesh.

2. To analyse the market efficiency in different grade regulated markets of wheat in Madhya Pradesh.

\section{METHODOLOGY}

The study confined to randomly select A (Sehore), B (MHOW), C (Kalapipal) and D (Katangi) grade of regulated market of wheat in Mdhya Pradesh. The study is purely based on secondary data related to different market facilities and expenditure and income generation by these regulated markets. These data have been collected from online and offline records of M.P. State Agricultural

Table 1: Number of regulated markets of different grade in different divisions of Madhya Pradesh

\begin{tabular}{ccccccccc}
\hline Grade & Bhopal & Indore & Ujjain & Gwalior & Sagar & Jabalpur & Rewa & Total \\
\hline A & 19 & 7 & 11 & 4 & 3 & 6 & 1 & 51 \\
B & 6 & 10 & 7 & 5 & 4 & 6 & 2 & 40 \\
C & 10 & 9 & 12 & 11 & 9 & 6 & 1 & 58 \\
D & 14 & 7 & 12 & 25 & 20 & 17 & 14 & 109 \\
Total & $\mathbf{4 9}$ & $\mathbf{3 3}$ & $\mathbf{4 2}$ & $\mathbf{4 5}$ & $\mathbf{3 6}$ & $\mathbf{3 5}$ & $\mathbf{1 8}$ & $\mathbf{2 5 8}$ \\
\hline
\end{tabular}


Marketing Board, Bhopal for the year 2011-12. The marketing efficiency was analysed through following Shepherd's Equation i.e. Ratio of Annual income and the Annual expenditure of the particular regulated market.

Shepherd's Equation $=\frac{v}{i}-1$

$\mathrm{v}=$ Annual income of the particular regulated market

$\mathrm{i}=$ Annual expenditure of the particular regulated market

\section{RESULTS AND DISCUSSION}

The facilities and services available and market efficiency of different grade of regulated markets have been analysed for the study.

\section{Facilities and Services}

The facilities and services available in the different grade of regulated markets of wheat are presented in Table 2. It is observed from the data that in A grade (Sehore) regulated market all the facilities were available viz. information notice board/electric display board, public address system, display of prices on the notice board and producers able to read the information displayed on the notice board. The facilities of canteen, toilets, internal roads, parking, fencing, bank, input/sundry shops, rest house, drinking water, electricity, auction platform, mechanical graders, sieves, garbage disposal system, sweeping facilities, information unit, extension unit and audio visual side except restaurant, post office, fire extinguishers, grading and analysing laboratory. Market office has also found to be available in these

Table 2: Facilities and services available in different grade regulated markets of wheat in Madhya Pradesh

\begin{tabular}{|c|c|c|c|c|c|}
\hline S1. No & Particulars & Grade A & Grade B & Grade C & Grade D \\
\hline 1 & Information Notice Board/Electric Display Board & $\sqrt{ }$ & $\sqrt{ }$ & $\sqrt{ }$ & $\sqrt{ }$ \\
\hline 2 & Public Address System & $\sqrt{ }$ & $\sqrt{ }$ & $\mathrm{x}$ & $\mathrm{x}$ \\
\hline 3 & Are the prices displayed on the Notice Board & $\sqrt{ }$ & $\sqrt{ }$ & $\sqrt{ }$ & $\sqrt{ }$ \\
\hline 4 & $\begin{array}{l}\text { Are the producers able to read the information } \\
\text { displayed on The Notice Board }\end{array}$ & $\sqrt{ }$ & $\sqrt{ }$ & $\sqrt{ }$ & $\sqrt{ }$ \\
\hline 5 & Facilities availability & & & & \\
\hline$a$ & Canteen & $\sqrt{ }$ & $\sqrt{ }$ & $\sqrt{ }$ & $\sqrt{ }$ \\
\hline$b$ & Restaurant & $x$ & $\sqrt{ }$ & $x$ & $x$ \\
\hline$c$ & Toilets & $\sqrt{ }$ & $\sqrt{ }$ & $\sqrt{ }$ & $\sqrt{ }$ \\
\hline$d$ & Internal Roads & $\sqrt{ }$ & $\sqrt{ }$ & $\sqrt{ }$ & $x$ \\
\hline$e$ & Parking & $\sqrt{ }$ & $\sqrt{ }$ & $\sqrt{ }$ & $x$ \\
\hline$f$ & Fencing & $\sqrt{ }$ & $\sqrt{ }$ & $\sqrt{ }$ & $\sqrt{ }$ \\
\hline$g$ & Post Office & $x$ & $x$ & $x$ & $x$ \\
\hline$h$ & Bank & $\sqrt{ }$ & $x$ & $x$ & $x$ \\
\hline$i$ & Input/Sundry Shops & $\sqrt{ }$ & $\sqrt{ }$ & $\sqrt{ }$ & $\sqrt{ }$ \\
\hline j & Fire Extinguishers & $x$ & $\sqrt{ }$ & $\mathrm{x}$ & $x$ \\
\hline$k$ & Rest house for farmers & $\sqrt{ }$ & $\sqrt{ }$ & $\mathrm{x}$ & $\mathrm{x}$ \\
\hline$l$ & Drinking Water & $\sqrt{ }$ & $\sqrt{ }$ & $\sqrt{ }$ & $\sqrt{ }$ \\
\hline$m$ & Electricity & $\sqrt{ }$ & $\sqrt{ }$ & $\sqrt{ }$ & $\sqrt{ }$ \\
\hline$n$ & Auction Platform & $\sqrt{ }$ & $\sqrt{ }$ & $\sqrt{ }$ & $\sqrt{ }$ \\
\hline$o$ & Grading and Analysing Laboratory & $x$ & $\mathrm{x}$ & $\sqrt{ }$ & $\sqrt{ }$ \\
\hline$p$ & Mechanical Graders & $\sqrt{ }$ & $\sqrt{ }$ & $\sqrt{ }$ & $\sqrt{ }$ \\
\hline$q$ & Sieves & $\sqrt{ }$ & $\sqrt{ }$ & $\sqrt{ }$ & $\sqrt{ }$ \\
\hline$r$ & Garbage Disposal System & $\sqrt{ }$ & $x$ & $\sqrt{ }$ & $\sqrt{ }$ \\
\hline$s$ & Sweeping Facilities & $\sqrt{ }$ & $\sqrt{ }$ & $\sqrt{ }$ & $x$ \\
\hline$t$ & Information Unit & $\sqrt{ }$ & $\sqrt{ }$ & $\sqrt{ }$ & $\sqrt{ }$ \\
\hline$u$ & Extension Unit & $\sqrt{ }$ & $\mathrm{X}$ & $x$ & $\sqrt{ }$ \\
\hline$v$ & Audio Visual side & $\sqrt{ }$ & $\sqrt{ }$ & $x$ & $x$ \\
\hline$w$ & Market office building & $\sqrt{ }$ & $\sqrt{ }$ & $\sqrt{ }$ & $\sqrt{ }$ \\
\hline 6 & Name of Welfare scheme for producers & $\begin{array}{c}\text { Chief Minister } \\
\text { Farmers } \\
\text { Welfare } \\
\text { Programme }\end{array}$ & $\begin{array}{c}\text { Chief Minister } \\
\text { Farmers } \\
\text { Welfare } \\
\text { Programme }\end{array}$ & $\begin{array}{c}\text { Chief Minister } \\
\text { Farmers } \\
\text { Welfare } \\
\text { Programme }\end{array}$ & $\begin{array}{c}\text { Chief Minister } \\
\text { Farmers } \\
\text { Welfare } \\
\text { Programme }\end{array}$ \\
\hline
\end{tabular}


regulated markets. The farmers' welfare programme has also found operating in all the regulated market. The facility of bank, garbage disposal system and extension unit have not been available in $\mathrm{B}$ grade regulated market. As regards in $\mathrm{C}$ grade (Kalapipal) and $\mathrm{D}$ grade (Katangi) regulated market there have also been facilities of the facilities available in B grade regulated market But facility of restaurant, post office, bank, fire extinguishers, rest house for farmers, extension unit and audio visual side have not been found in these particular grade of regulated markets.

\section{Market Profile}

The general information, market area, market functionaries, transactional methods, transportation and storage and other facilities and services are analysed and presented in Table 3.

Table 3: Market Profile of different grade regulated markets of wheat in Madhya Pradesh

\begin{tabular}{|c|c|c|c|c|c|}
\hline $\begin{array}{l}\text { Sl. } \\
\text { No }\end{array}$ & Particulars & $\begin{array}{c}\text { Grade } \\
\text { A }\end{array}$ & $\begin{array}{c}\text { Grade } \\
\text { B }\end{array}$ & $\begin{array}{c}\text { Grade } \\
\text { C }\end{array}$ & $\begin{array}{c}\text { Grade } \\
\text { D }\end{array}$ \\
\hline 1 & Year of Working & 46 & 26 & 31 & 48 \\
\hline 2 & Population served & 500000 & 300000 & 120000 & 80000 \\
\hline 3 & $\begin{array}{l}\text { No. of village } \\
\text { served }\end{array}$ & 161 & 177 & 142 & 126 \\
\hline 4 & Operational hours & 12 & 7 & 8 & 7 \\
\hline 5 & Peak trading hours & 8 & 7 & 8 & 3 \\
\hline 6 & \multicolumn{5}{|c|}{ Number of staff members } \\
\hline a & Supervisory & 27 & 39 & 20 & 12 \\
\hline$b$ & Administrative & 28 & 1 & 1 & 1 \\
\hline 7 & $\begin{array}{l}\text { Distance of the } \\
\text { railway station } \\
\text { from the market } \\
\qquad(\mathrm{Km})\end{array}$ & 1 & 3 & 2 & 2 \\
\hline 8 & $\begin{array}{l}\text { Distance of the } \\
\text { Nearest National } \\
\text { /State Highway } \\
(\mathrm{Km})\end{array}$ & 3 & 4 & 20 & 2 \\
\hline 9 & $\begin{array}{l}\text { Processing units in } \\
\text { the Market area }\end{array}$ & 1 & 2 & 0 & 0 \\
\hline 10 & $\begin{array}{l}\text { Number of Cold } \\
\text { Storages with } \\
\text { capacity }\end{array}$ & 0 & $\begin{array}{c}4 \\
(800 \\
\text { MT })\end{array}$ & 0 & 0 \\
\hline 11 & $\begin{array}{l}\text { Number of } \\
\text { Ripening Chambers } \\
\text { with capacity }\end{array}$ & 0 & 0 & 0 & $\begin{array}{c}1 \\
(2 \mathrm{MT})\end{array}$ \\
\hline 12 & $\begin{array}{l}\text { Number of } \\
\text { Commodities } \\
\text { notified under } \\
\text { regulation }\end{array}$ & 135 & 135 & 0 & 1 \\
\hline
\end{tabular}

Average daily

dispatches to

outside markets

during the season

(M.T.)

14

Average daily

dispatches to

outside markets

during the peak period(M.T.)

15 Number of markets

(important) to

which produce is sent

16 Modes of transport Bullock Truck, Bullock Bullgenerally adopted cart Tractor, Carts, ock for the market Trucks, Load- Trans- Carts, Tractors, ing port TrolTempo Rick- Trolley, ley, shaw Tempo Tempo

17 Number of Licensed Functionaries

\begin{tabular}{cccccc} 
a & Traders & 160 & 151 & 55 & 22 \\
b & Processor & 7 & 1 & 1 & 2 \\
c & Tulawati & 51 & 7 & 1 & 86 \\
d & Hammal & 222 & 205 & 195 & 187 \\
e & Store Keeper & 3 & 1 & 0 & 0 \\
\hline
\end{tabular}

It is observed from the data that the A grade regulated market (Sehore) was found operated since 1970 and serving approximately 5 lakh population of 161 villages. The market operated for 12 hours, out of which 8 hours are peak operational hours. The number of processing unit was found to be 1 in this particular market area. There are 27 and 28 supervisory and administrative officers working in this regulated market. Market is found only $1 \mathrm{Km}$ away from railway station and $3 \mathrm{Km}$ away from National/State highway. There are 135 notified commodities arrived in the market. There have been found 8000 metric ton and 20000 metric ton daily dispatches to 6 outside markets viz. Indore, Dewas, Bhopal, Nagpur, Jabalpur and Mumbai during season and peak period. The main modes of transportations are found to be bullock cart, tractor trolley, truck, and tempo. There are 160, 7, 51, 222 and 3 traders, processors, tulawati, hammals and store keepers respectively are working in the regulated market.

As regard in the $\mathrm{B}$ grade $(\mathrm{MHOW})$ regulated market was found operated 1990 and serving approximately 3 lakh populations of 177 villages. The market operated 7 hours. There are 39 and 01 
supervisory and administrative officers working in this particular regulated market. Market is found 3 $\mathrm{Km}$ away from railway station and $4 \mathrm{Km}$ away from National/State highway. The number of processing unit is 2 . There are 4 cold storages of 800 metric ton also observed in this market. There are 135 notified commodities arrived in the market. There are 300 metric ton and 1000 metric ton daily dispatches to 4 outside markets viz. Indore, Pithampur, Pune and Mumbai during season and peak period. The main modes of transportations were found to be bullock cart, tractor, trucks, and tempo. There were 151, 01, 07, 205 and 1 traders, processors, tulawatis, hammals and store keepers respectively working in the regulated market.

The C grade (Kalapipal) regulated market was found operating since 31 years (1985) and serving approximately 1.2 lakh populations of 142 villages. The market operated for 8 hours. There are 20 and 01 supervisory and administrative officers working in this regulated market. Market is found $2 \mathrm{Km}$ away from railway station and $20 \mathrm{Km}$ away from National/State highway. There was not found any processing unit cold storages, ripening chambers found in the market. There are 250 metric ton and 500 metric ton daily dispatches to 4 outside markets viz. Indore, Devas, Bhopal and Nagpur during season and peak period. The main modes of transportations are found to be bullock cart, tractor trolley, and tempo. There are found to be 55, 01, 01 and 195 traders, processors, tulawatis and hammals in the regulated market.

The D grade (Katangi) regulated market was found to be operated since 48 years (1968) and serving approximately 0.8 lakh populations of 126 villages. The market operated for only 7 hours, out of which only 3 hours are found peak operational hours. There are 12 and 01 supervisory and administrative officers working in this regulated market. Market is found $2 \mathrm{Km}$ away from railway station as well as National/State highway. There are no processing unit cold storages found in the market, although market have 01 Ripening chamber (02 metric ton) and 01 notified commoditie i.e. paddy arrived in the market. There are 100 and 300 metric ton daily dispatches to 4 outside markets viz. Balaghat, Gondiya, Nagpur and Jabalpur. The main modes of transportations are bullock cart, trolley and tempo. There are 22, 02, 86, 187 and 1 traders, processors, tulawati, hammals and store keepers respectively found in the regulated market.

\section{Market Efficiency}

The Market efficiency of different grade of regulated markets of wheat are also analysed and presented in Table 4. It is observed from the data that A grade (Sehore) regulated market obtained an annual income of ₹ 670.25 lakh with the total annual expenditure of ₹ 1670.19 lakh. Hence, there is found a deficit of ₹ 999.93 lakh. The total liabilities of the regulated market were found to be ₹ 218.38 lakh. The Market efficiency of this particular grade of regulated market is $1:-0.60$.

Table 4: Price efficiency in different grade of regulated markets of wheat in Madhya Pradesh. (₹)

(2011-12)

\begin{tabular}{cccccc}
\hline Sl. & Particulars & $\begin{array}{c}\text { Grade } \\
\text { A }\end{array}$ & $\begin{array}{c}\text { Grade } \\
\text { B }\end{array}$ & $\begin{array}{c}\text { Grade } \\
\text { C }\end{array}$ & $\begin{array}{c}\text { Grade } \\
\text { D }\end{array}$ \\
\hline 1 & Annual Income & 670.25 & 565.45 & 348.94 & 50.00 \\
2 & Annual & 1670.19 & 563.61 & 384.98 & 48.00 \\
3 & $\begin{array}{c}\text { Expenditure } \\
\text { Surplus/Deficit }\end{array}$ & -999.94 & 1.84 & -36.04 & 2.00 \\
4 & $\begin{array}{c}\text { Total Reserves } \\
\text { with APMC }\end{array}$ & 0.00 & 381.36 & 0.00 & 55.66 \\
5 & $\begin{array}{c}\text { Total Liabilities } \\
\text { Market Efficiency }\end{array}$ & 218.38 & 396.10 & 40.98 & 56.86 \\
6 & $\begin{array}{c}\text { (As per Shepherd's } \\
\text { Equation) }\end{array}$ & -0.60 & 0.003 & -0.094 & 0.042 \\
\hline
\end{tabular}

The B grade (MHOW) regulated market showed a different picture. Market obtained an annual income of ₹ 565.45 lakh with the total annual expenditure of ₹ 563.61 lakh. There is found surplus of ₹ 1.84 lakh. The total liabilities of the regulated market are only ₹ 396.10 lakh. The market efficiency of this regulated market is 1:0.003.

The C grade (Kalapipal) regulated market also obtained an annual income of ₹ 348.94 lakh with the total annual expenditure of ₹ 384.98 lakh. (Fig. 1) There is a defect of ₹ 36.04 lakh. The total liabilities of the regulated market are ₹ 40.98 lakh. The market efficiency of this particular grade of regulated market is 1: 0.094. The D grade (Katangi) regulated market obtained an annual income of ₹ 50.00 lakh with the total annual expenditure of ₹ 48.00 lakh. There was found surplus of ' 2.00 lakh. The total liabilities of the $\mathrm{D}$ grade regulated market found more (₹ 56.86 lakh) as compared to 


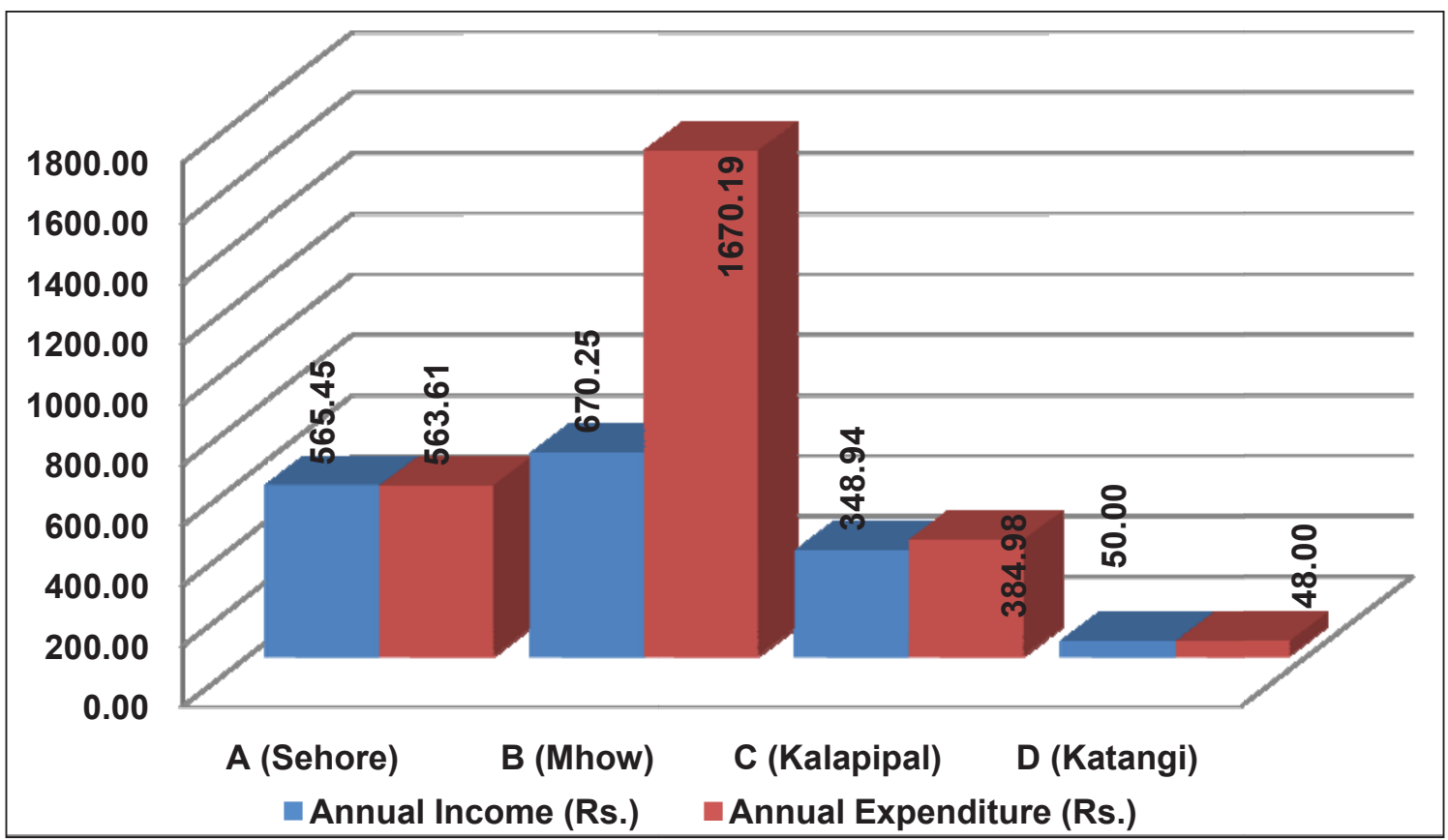

Fig. 1: Comparative picture of annual income and expenditure of different grade of regulated markets of wheat in Madhya Pradesh

$\mathrm{C}$ grade regulated market. The market efficiency of this particular grade of regulated market is 0.042 . Hence, it is concluded from the results that D grade regulated market is found more efficient than $B$ grade, $\mathrm{C}$ grade and $\mathrm{A}$ grade regulated markets for marketing of wheat.

\section{CONCLUSION}

A grade (Sehore) regulated market has found to facilitate more than the other market but this particular market has found less efficiency than the other market. All the market has poor market facilities with regards to post office, restaurant, fire extinguishers, bank, grading and analysing laboratory, extension unit, public address system, rest house for farmers, audio visual side and garbage disposal system. Hence suggested that these facilities should be provided in each regulated markets with National e-agriculture market (e-markets) and bringing them all to one platform so that registered farmers will be able to sell their produce online in any of the markets where they can get the best price. The $e$-market also ensured that intermediaries (and money lenders) do not compel farmers to sell their produce at throw away prices and their produce should first be bought at the regulated market to be put for auction to sell, which will get them all a fair price, reduce the chances of middlemen by adding any extra cost or seeking double commission. This also brought transparency in the system.

\section{REFERENCES}

Acharya, S.S., Chand, R., Birthal, P. S., Kumar, Shiv and Negi, D.S. 2012. Market Integration and Price Transmission in India: A Case of Rice and Wheat with Special Reference to the World Food Crisis of 2007-08. Food and Agriculture Organization, Rome, pp. 1-67.

Anonymous, 2013. Agricultural Statistics at a Glance 2013, Directorate of Economics and Statistics, Department of Agriculture and Cooperation, Ministry of Agriculture, Government of India.

Anonymous., 2015. Commodity Profile for Wheat, Directorate General of Foreign Trade (DGFT) India.

Anonymous, 2015. Madhya Pradesh at a Glance, National Information Centre, Government of Madhya Pradesh.

Anonymous., 2015. M.P. State Agricultural Marketing Board i.e. MPSAMB, available on www.mpmandiboard.com2015

Asmatoddin, Mohd., Satpute, T.G. and Maske, V.S. 2009. Arrival and price behaviour of important pulse crops in Parbhani district. International Journal of Agricultural Sciences, 2: 428-430.

Tomar V.S. 2015. Online National Agriculture MarketEmpowering Farmers and Stabilising Food Prices. Employment News, 40(18): 48. 